\title{
PENGARUH PROSENTASE PENAMBAHAN ETHANOL PADA BAHAN BAKAR PERTALITE TERHADAP DAYA DAN TORSI PADA MESIN MOTOR MATIC 125 CC
}

\author{
Effect of Percentage Addition of Ethanol on Pertalite Fuel Power and Torque in Motor Machines \\ Matic 125 CC
}

\author{
Muh. Andrean Wahyu $\mathbf{P}^{1^{*}}$, Nely Ana Mufarida ${ }^{2}$, Kosjoko $^{3}$ \\ ${ }^{1,2,3)}$ Jurusan Teknik Mesin, Fakultas Teknik, Universitas Muahammadyah Jember \\ Email: ${ }^{1)}$ andrewahyu20337@gmail.com, ${ }^{2}$ nelyana munfarida@yahoo.com
}

\begin{abstract}
ABSTRAK
Tujuan dari penelitian ini adalah untuk mengetahui pengaruh penambahan ethanol dengan pertalite pada torsi dan daya sepeda motor matic $125 \mathrm{cc}$. Penelitian ini merupakan eksperimen. Sampel diambil dengan menggunakan teknik pengambilan sampel standart. Sampel penelitian adalah sepeda motor Matic 125cc. Data torsi dan daya diperoleh dengan menggunakan Dynotest Sportdyno V3.3. Data penelitian adalah, daya dan torsi dari variasi campuran ethanol 0\%, 10\%, dan 20\%. Berdasarkan hasil penelitian, dapat disimpulkan bahwa pertama, penambahan ethanol pertalite dapat mengurangi torsi dan daya sepeda motor. kedua, torsi tertinggi dari pengujian yaitu 12,52 Nm, ditemukan untuk penambahan ethanol 10\% dengan pemanasan bahan bakar, sedangkan torsi terendah, yaitu $6.78 \mathrm{Nm}$, ditemukan dengan variasi penambahan ethanol $0 \%$, dan ketiga, daya tertinggi yaitu 8,4 HP, ditemukan dengan variasi penambahan ethanol $10 \%$, sedangkan daya terendah, yaitu 2,6 HP, ditemukan dengan penambahan ethanol $0 \%$.
\end{abstract}

Kata kunci : Bahan bakar, ethanol, putaran, daya dan torsi.

\begin{abstract}
The purpose of this study was to determine the effect of ethanol addition with pertalite on the torque and power of $125 \mathrm{cc}$ matic motorbikes. This research is an experiment. Samples were taken using standart sampling technique. The research sample is Matic $125 \mathrm{cc}$ motorcycle. Torque and power data is obtained using Dynotest Sportdyno V3.3. The research data are, the power and torque of the variation of ethanol mixture 0\%, 10\%, and 20\%. Based on the results of the study, it can be concluded that first, adding ethanol pertalite can reduce torque and motorbike power. Second, the highest torque of the test is 12.52 $\mathrm{Nm}$, found for the addition of $10 \%$ ethanol by heating the fuel, while the lowest torque, which is 6.78 $\mathrm{Nm}$, is found with a variation of 0\% ethanol, and third, the highest power is $8.4 \mathrm{HP}$ found with a variation of $10 \%$ ethanol addition, while the lowest power, which is $2.6 \mathrm{HP}$, was found with the addition of $0 \%$ ethanol.
\end{abstract}

Keywords: Fuel, ethanol, rotation, power and torque.

\section{PENDAHULUAN}

Latar Belakang

Perkembangan ilmu pengetahuan dan tekonologi terus melaju tak terbendung lagi di segala bidang, terutama dalam bidang otomotif. Perkembangan teknologi selalu membawa dampak positif dan negatif tetapi dari teknologi yang diciptakan diharapkan seminimal mungkin membawa dampak negatif. Semakin bertambahnya jumlah penduduk di bumi khususnya di Indonesia tentu dibutuhkan alat transportasi untuk menunjang segala macam aktivitas dalam kehidupan sehari-hari. Dengan keadaan alat transportasi umum yang belum baik di Indonesia terutama di kota-kota besar kendaraan pribadi masih menjadi pilihan yang banyak digunakan oleh masyarakat perkotaan, seperti halnya di Jakarta, Surabaya, Bandung dan kota-kota besar lainnya di Indonesia. Sepeda motor masih menjadi pilihan utama 
masyarakat Indonesia dibandingkan alat transportasi lainnya, dari data Badan Pusat Statistik Republik Indonesia (BPS-RI) dari tahun 1987 sampai tahun 2012 tercatat sebanyak 76.381.183 unit sepeda motor terjual di Indonesia atau sepertiga dari jumlah penduduk Indonesia. Mayoritas pengguna sepeda motor masih menggunakan Bahan Bakar Minyak (BBM) jenis pertalite yang disubsidi oleh pemerintah. Akibat pelemahan nilai tukar rupiah yang terjadi sejak pertengahan tahun 2013, belanja pemerintah pada anggaran negara kembali membengkak.

Di Indonesia sedang gencar dikembangkan bahan bakar alternatif, salah satunya adalah ethanol karena sumber bahan baku dari ethanol tidaklah susah. Indonesia merupakan negara tropis yang sangat cocok untuk menanam tanaman bahan baku ethanol seperti tebu dan ketela. Bahan baku dalam pembuatan ethanol bisa mengunakan ketela dan tetes tebu. Ethanol merupakan salah satu bahan bakar alternatif yang mempunyai kelebihan dibandingkan BBM. Ethanol dengan kadar alkohol 70\% memiliki angka oktan 118 (Joko Winarno, 2011), sementara pertalite yang dijual oleh Pertamina hanya memiliki angka oktan 90. Proses pembakaran merupakan proses yang paling menentukan tenaga yang dihasilkan sebuah sepeda motor di samping faktor-faktor lain seperti kapasitas mesin, cara berkendara, dan usia dari sepeda motor itu sendiri. Syarat terjadinya proses pembakaran di dalam ruang bakar ada tiga, yaitu campuran udara dan bahan bakar, kompresi dan percikan bunga api dari busi. Dari proses pembakaran itu sendiri masih dapat diuraikan lagi menjadi beberapa faktor antara lain, jenis bahan bakar, kualitas bahan bakar yang digunakan, sistem pengapian, dan sistem bahan bakar. Sistem bahan bakar merupakan sistem yang bertugas mensuplai campuran bahan bakar ke ruang bakar sesuai dengan kondisi kerja mesin. Apabila sistem bahan bakar dapat mensuplai campuran udara dan bensin dengan homogen serta rasio yang ideal maka akan didapatkan hasil pembakaran yang sempurna dan tenaga yang maksimal. Pemanasan bahan bakar yang dilakukan sebelum bensin masuk ke dalam sistem bahan bakar/karburator dapat membantu proses pengkabutan. Proses pemanasan bahan bakar bensin dapat meningkatkan angka oktan bahan bakar.

\section{Rumusan Masalah}

Dari uraian diatas menjelaskan permasalahan utama maka penulis memaparkan rumusan - rumusan masalah yang akan dibahas diantaranya:

1. Bagaimana pengaruh variasi pengaruh bahan bakar dari campuran Ethanol terhadap daya dan torsi?
2. Bagaimana hasil pengujian dalam penggunaan Ethanol pada motor matic $125 \mathrm{cc}$ ?

\section{Batasan Masalah}

Dari penelitian ini, penulis membatasi dalam permasalahan - permasalahan yang telah dipaparkan diatas, diantaranya:

1. Motor yang digunakan adalah motor matic $125 \mathrm{cc}$ yang berbahan bakar Pertalite.

2. Parameter yang akan diteliti adalah uji daya dan torsi.

3. Putaran mesin yang diinginkan yaitu $3000 \mathrm{rpm}$, $3500 \mathrm{rpm}, 4000 \mathrm{rpm}, 4500 \mathrm{rpm}, 5000 \mathrm{rpm}, 5500$ rpm, dan $6000 \mathrm{rpm}$.

\section{Tujuan Penelitian}

Adapun tujuan dari hasil penelitian yang dilakukan untuk memenuhi tugas proposal skripsi ini maka penulis memaparkan tujuan penelitiannya, diantaranya:

1. Untuk mengetahui pengaruh variasi pencampuran bahan bakar dan Ethanol terhadap daya dan torsi.

2. Untuk mengetahui hasil pengujian dalam penggunaan Ethanol pada motor matic $125 \mathrm{cc}$.

\section{Manfaat Penelitian}

Adapun manfaat dari hasil penelitian yang dilakukan ini untuk memenuhi tugas proposal skripsi, maka penulis memaparkan manfaat - manfaat dari penelitiannya sebagai berikut:

1. Bagi Perusahaan (PT) sebagai pengembangan dibidang teknologi sebagai upaya untuk meningkatkan inovasi untuk produksi selanjutnya.

2. Bagi Mahasiswa sebagai bahan referensi dikampus untuk menambah ilmu pengetahuan dengan adanya penemuan peneliti selanjutnya.

3. Bagi Masyarakat untuk memberikan peran kesadaran dalam penggunaan konsumsi bahan bakar pada kendaraan bermotor.

\section{TINJAUAN TEORI}

\section{Bahan Bakar}

Bahan bakar merupakan setiap material yang dapat terbakar dan melepaskan energi. Bahan bakar secara umum terdiri dari hidrogen dan karbon dan dituliskan dengan rumus umum berupa $\mathrm{CnHm}$ (Muchammad, 2010:31). Bahan bakar merupakan material, zat atau benda yang digunakan dalam proses pembakaran untuk menghasilkan energi panas (Raharjo dan Karnowo, 2008:37).

Bahan bakar dibagi menjadi tiga jenis, yaitu:

1. Bahan bakar fosil.

2. Bahan bakar mineral.

3. Bahan bakar nabati atau organik. 
Sampai dengan saat ini bahan bakar yang sering digunakan adalah jenis bahan bakar cair dan fosil. Diantaranya yaitu bensin dan solar yang banyak digunakan untuk bahan bakar mesin pada motor bakar.

Syarat utama yang harus dipenuhi bahan bakar yang akan digunakan dalam motor

bakar yaitu:

1. Proses pembakarannya harus cepat dan panas yang dihasilkan harus tinggi.

2. Bahan bakar tidak meninggalkan endapan setelah pembakaran, karena akan merusak dinding silinder.

3. Gas sisa pembakaran harus tidak berbahaya pada saat terbuang ke atmosfer.

Sifat pada masing-masing bahan bakar berbeda.

Sifat ini akan menentukan dalam proses pembakarannya, sifat yang kurang menguntungkan dapat disempurnakan dengan menambahkan bahan kimia ke dalam bahan bakar tersebut (Supraptono, 2004:33).

Supraptono (2004:25-29) menjelaskan sifat-sifat fisika bahan bakar minyak yaitu:

1. Berat Jenis.

Berat jenis atau specific grafity adalah suatu perbandingan berat dari bahan bakar minyak dengan berat dari air dalam volume yang sama, dengan suhu yang sama pula $(600 \mathrm{~F})$. Bahan bakar minyak umumnya mempunyai berat jenis antara 0,82-0,96 dengan kata lain minyak lebih ringan dari pada air. Dalam perdagangan internasional, berat jenis dinyatakan dalam API Grafity atau derajat API (American Petroleum Institute). API menunjukkan kualitas dari minyak tersebut, makin kecil berat jenis atau makin tinggi derajat API berarti makin baik pula kualitas minyak tersebut, karena lebih banyak mengandung bensin.

2. Viskositas.

Viskositas adalah suatu ukuran dari besar perlawanan zat cair untuk mengalir. Viskositas atau kekentalan sangat penting bagi penggunaan bahan bakar minyak pada motor bakar maupun mesin industri, karena berpengaruh terhadap bentuk dan tipe mesin yang menggunakan bahan bakar tersebut.

\section{Nilai Kalor.}

Nilai kalor adalah besar panas yang diperoleh dari pembakaran suatu bahan bakar di dalam zat asam. Makin tinggi berat jenis minyak bakar, makin rendah nilai kalori yang diperolehnya. Misalnya bahan bakar minyak dengan berat jenis 0,75 atau grafitasi API 70,6 mempunyai nilai kalor $11.700 \mathrm{kal} / \mathrm{kg}$.

4. Titik Tuang.
Titik tuang suatu minyak adalah suhu terendah minyak yang keadaannya masih dapat mengalir karena berat sendiri. Titik tuang diperlukan sehubungan dengan kondisi dari pengilangan dan pemakaian dari minyak tersebut. Sehingga diharapkan minyak masih bisa dipompakan atau mengalir pada suhu dibawah titik tuang.

5. Titik Didih.

Titik didih adalah suhu ketika tekanan uap suatu zat cair sama dengan tekanan luar yang dialami oleh cairan. Titik didih minyak sesuai dengan grafitasinya. Minyak dengan grafitasi API rendah maka titik didihnya tinggi, dan untuk minyak dengan grafitasi API tinggi maka titik didihnya rendah.

6. Titik Nyala.

Titik nyala adalah suhu terendah suatu bahan bakar minyak yang dapat menimbulkan nyala api dalam sekejap apabila permukaan bahan bakar tersebut dipercikkan api. Pada bahan bakar dengan grafitasi API yang tinggi maka titik didihnya rendah, sehingga titik nyala bahan bakar tersebut juga rendah. Artinya bahan bakar tersebut akan mudah untuk terbakar.

\section{Kadar Abu}

Kadar abu adalah sisa-sisa bahan bakar minyak yang tertinggal setelah semua bagian terbakar dalam proses pembakaran. Berdasarkan kadar abu yang ada dalam bahan bakar minyak akan dapat diperkirakan banyaknya kandungan logam dalam minyak tersebut.

\section{Air dan Endapan}

Air yang terkandung dalam bahan bakar minyak dapat menyebabkan pembakaran yang tidak sempurna, sedangkan endapan dapat memperbanyak jumlah gas sisa pembakaran. Kandungan air dan endapan dalam minyak tidak boleh lebih dari $0,5 \%$.

9. Warna

Warna dalam bahan bakar minyak dipengaruhi oleh berat jenisnya. Untuk minyak dengan berat jenis yang tinggi memiliki warna hijau kehitaman dan untuk minyak dengan berat jenis yang rendah warnanya akan cokelat kehitaman. Hal ini disebabkan oleh adanya kotoran dan endapan dalam bahan bakar minyak tersebut.

10. Bau

Bau dari bahan bakar dipengaruhi oleh molekul aromat yang terkandung didalamnya. Bahan bakar minyak di Indonesia pada umumnya mengandung senyawa Nitrogen atau Belerang dan juga H2S.

Kristanto dkk., (2001:57) menjelaskan bahwa makin tinggi angka oktan maka makin rendah kecenderungan bahan bakar untuk terjadi knocking. 
Motor dengan perbandingan kompresi yang tinggi memerlukan angka oktan yang lebih tinggi juga untuk mengurangi knocking. Dengan melihat nilai oktan dari suatu bahan bakar kita dapat menentukan karakteristik bahan bakar tersebut selain itu, untuk bahan bakar dengan nilai oktan tinggi dikhususkan untuk mesin dengan kompresi yang tinggi juga untuk mendapatkan tenaga yang lebih tinggi.

Berikut ini adalah nilai oktan dari jenis bahan bakar. Tabel 2.1 Nilai-Nilai Oktan dari Jenis Bahan Bakar Beserta Rasio Kompresi

\begin{tabular}{|l|c|c|}
\hline \multicolumn{1}{|c|}{ Jenis BBM } & Nilai Oktan & Rasio Kompresi \\
\hline Premium & 88 & $7: 1-9: 1$ \\
\hline Pertalite & 90 & $9: 1-10: 1$ \\
\hline Pertamax & 92 & $10: 1-11: 1$ \\
\hline Pertamax Plus & 95 & $11: 1-12: 1$ \\
\hline
\end{tabular}

\section{Pertalite}

Bahan bakar Pertalite adalah bahan bakar minyak terbaru dari Pertamina dengan RON 90. Bahan bakar pertalite direkomendasikan untuk kendaraan dengan kompresi 9:1 sampai 10:1 dan khususnya untuk kendaraan yang telah menggunakan sistem EFI (Electronic Fuel Injection) dan catalytic converter. Selain itu dengan RON 90 diharapkan pertalite dapat membuat pembakaran pada mesin kendaraan lebih baik dibandingkan dengan premium dengan RON 88. Bahan bakar pertalite diluncurkan oleh Pertamina untuk memenuhi syarat Keputusan Dirjen Migas No.313.K/10/DJM.T/2013 tentang spesifikasi BBM dengan RON 90.

Tabel 2.2 Standar dan Mutu Bahan Bakar Jenis Pertalite

\begin{tabular}{|c|c|c|c|c|c|c|}
\hline NL & \multirow{2}{*}{ Karakteristik } & \multirow{2}{*}{ Satuan } & \multicolumn{2}{|c|}{ Batasan } & \multicolumn{2}{|c|}{ Metode Uji } \\
\hline No & & & Min & Max & ASTM & Lain \\
\hline 1 & $\begin{array}{l}\text { Bilangan Oktan } \\
\text { Angka Oktan } \\
\text { Riset (RON) } \\
\text { Angka Oktan } \\
\text { Motor (MON) }\end{array}$ & $\begin{array}{l}\text { RON } \\
\text { MON }\end{array}$ & $\begin{array}{c}90 \\
\text { Dilaporkan }\end{array}$ & - & $\begin{array}{l}\text { D } 2699 \\
\text { D } 2700\end{array}$ & \\
\hline 2 & Stabilitas Oksidasi & Menit & 360 & & D 525 & \\
\hline 3 & Kandungan Sulfur & $\% \mathrm{~m} / \mathrm{m}$ & - & 0,05 & $\begin{array}{c}\text { D 2622 } \\
\text { atau D } \\
4294 \\
\text { atau D } \\
7039\end{array}$ & \\
\hline 4 & $\begin{array}{l}\text { Kandungan } \\
\text { Timbal (Pb) }\end{array}$ & $g / 1$ & $\begin{array}{c}\text { Injeksi } \\
\text { timbal } \\
\text { tidak } \\
\text { diijinkan }\end{array}$ & dilaporkan & D 3237 & \\
\hline 5 & $\begin{array}{l}\text { Kandungan } \\
\text { Logam (mangan, } \\
\text { besi) }\end{array}$ & $\mathrm{Mg} / 1$ & Tidak T & rdeteksi & D 3831 & IP74 \\
\hline 6 & $\begin{array}{l}\text { Kandungan } \\
\text { Oksigen }\end{array}$ & $\% \mathrm{~m} / \mathrm{m}$ & - & 2,7 & D 4815 & \\
\hline 7 & Kandungan Olefin & $\% \mathrm{v} / \mathrm{v}$ & & & D 1319 & \\
\hline 8 & $\begin{array}{l}\text { Kandungan } \\
\text { Aromatik }\end{array}$ & $\% \mathrm{v} / \mathrm{v}$ & & & D 1319 & \\
\hline 9 & $\begin{array}{l}\text { Kandungan } \\
\text { Benzena }\end{array}$ & $\% \mathrm{v} / \mathrm{v}$ & & & D 4420 & \\
\hline 10 & Distilasi & \begin{tabular}{|l}
${ }^{\circ} \mathrm{C}$ \\
${ }^{\circ} \mathrm{C}$
\end{tabular} & - & 74 & & \\
\hline
\end{tabular}

\begin{tabular}{|c|c|c|c|c|c|}
\hline 11 & Sedimen & $\mathrm{mg} / 1$ & - & 1 & D 5452 \\
\hline 12 & Unwashed Gum & $\mathrm{mg} / 100 \mathrm{ml}$ & - & 70 & D 381 \\
\hline 13 & Washed Gum & $\mathrm{mg} / 100 \mathrm{ml}$ & - & 5 & D 381 \\
\hline 14 & Tekanan Uap & $\mathrm{kPa}$ & 45 & 69 & D 5191 \\
\hline 15 & Berat Jenis $\left(15^{0} \mathrm{C}\right)$ & $\mathrm{Kg} / \mathrm{m}^{3}$ & 715 & 770 & D 4052 \\
\hline 16 & $\begin{array}{l}\text { Korosi bilah } \\
\text { tembaga }\end{array}$ & Menit & \multicolumn{2}{|c|}{ Kelas I } & D 130 \\
\hline 17 & Sulfur Mercaptan & $\%$ massa & - & 0,002 & D 3227 \\
\hline 18 & Penampilan Visual & & \multicolumn{2}{|c|}{ Jernih dan terang } & \\
\hline 19 & Bau & & \multicolumn{2}{|c|}{ Dapat dirasakan } & \\
\hline 20 & Warna & & \multicolumn{2}{|c|}{ Hijau } & \\
\hline 21 & $\begin{array}{l}\text { Kandungan } \\
\text { Pewarna }\end{array}$ & $\mathrm{g} / 100$ & - & 0,13 & \\
\hline
\end{tabular}

Sumber: (Kementerian Energi dan Sumber Daya Mineral Republik Indonesia Direktorat Jenderal Minyak dan Gas Bumi)

Pertalite membuat pembakaran pada mesin kendaraan lebih baik dibandingkan dengan premium. Purponegoro (2015) adapun keunggulan pertalite yaitu:

1. Durability, pertalite dikategorikan sebagai bahan bakar kendaraan yang memenuhi syarat dasar durability atau ketahanan, dimana bahan bakar ini tidak akan menimbulkan gangguan serta kerusakan mesin.

2. Fuel economy, kesesuaian oktan 90 pada pertalite dengan perbandingan kompresi kendaraan yang beroperasi sesuai dengan rancangannya. Perbandingan Air Fuel Ratio (AFR) yang lebih tinggi dengan konsumsi bahan bakar menjadikan kinerja mesin lebih optimal dan efisien untuk menempuh jarak yang lebih jauh.

3. Performance, kesesuaian angka oktan pertalite dan aditif yang dikandungnya dengan spesifikasi mesin akan menghasilkan performa mesin yang lebih baik dibandingkan ketika menggunakan oktan 88 . Hasilnya adalah torsi mesin lebih tinggi dan kecepatan meningkat.

\section{Ethanol}

Ethanol dikenal dengan nama alkohol yang memiliki rumus molekul $\mathrm{C}_{2} \mathrm{H}_{5} \mathrm{OH}$. Ethanol merupakan bahan kimia dalam bentuk cairan yang bening, tidak berwarna, mudah menguap, memiliki aroma yang tajam, dan terasa pedih di kulit (Wiratmaja, 2010:18). Alkohol atau ethanol merupakan bahan kimia yang diproduksi dari bahan baku tanaman yang mengandung pati seperti ubi kayu, ubi jalar, jagung, dan sagu (Nurdyastuti, 2005:75). Ethanol adalah bahan bakar beroktan tinggi dan dapat digunakan untuk meningkatkan nilai oktan dalam bensin (Sarjono dan Putra, 2013:4).

Alkohol pada umumnya mengandung 95 persen ethanol dan 5 persen air. Dalam kehidupan sehari-hari 
ethanol digunakan sebagai pelarut, bahan anti septik, bahan baku pembuatan eter, serta minuman keras. Ethanol juga dapat digunakan sebagai bahan bakar alternatif dan relatif aman terhadap lingkungan. Secara singkat proses produksi ethanol dibagi menjadi tiga tahap, yaitu proses gelatinasi, proses fermentasi dan proses distilasi. Nurdyastuti (2005:78) menjelaskan bahwa hasil fermentasi pada umumnya hanya menghasilkan ethanol dengan kemurnian 30 sampai 40 persen, oleh karena itu untuk memurnikan ethanol menjadi berkadar lebih dari 95 persen agar dapat digunakan sebagai bahan bakar harus melalui proses distilasi. Menurut Sarjono dan Putra (2013:4) penggunaan ethanol sebagai tambahan bahan bakar bensin mempunyai beberapa kelebihan dan kelemahan diantaranya yaitu:

1. Kelebihan dari penambahan ethanol dalam bahan bakar bensin: Alkohol dapat menyerap kelembaban dalam tangki bahan bakar, Penambahan alkohol sebesar sepuluh persen dapat meningkatkan nilai oktan sebesar kurang lebih 3 poin, Alkohol dapat membersihkan sistem bahan bakar, Alkohol dapat mengurangi emisi CO karena mengandung oksigen.

2. Kelemahan dari penggunaan ethanol dalam bahan bakar bensin: Alkohol dapat menyumbat saringan bahan bakar, Alkohol meningkatkan volatility bahan bakar sebesar 0,5 psi dan dapat menyebabkan masalah saat berkendara pada cuaca panas, Alkohol dapat menyerap air dan terpisah dari bensin, terutama pada temperatur rendah dan menyebabkan mesin sulit untuk dihidupkan.

Pada umumnya, ethanol memiliki angka oktan $107-$ 109, density 0,79 kg/L, A/F rasio 9, LHV sebesar $26.900 \mathrm{kcal} / \mathrm{kg}$, panas penguapan sebesar $840 \mathrm{kj} / \mathrm{kg}$ dan autoignition temperatur 423 0C (Sarjono dan Putra, 2013:4). Volatility pada bahan bakar menunjukkan kemampuan bahan bakar untuk menguap dan sifat ini penting, karena jika bahan bakar tidak cepat menguap maka bahan bakar akan sulit untuk bisa tercampur dengan udara pada saat pembakaran (Handayani, 2007:100). Volatility pada ethanol lebih rendah dan energi yang dihasilkan akan lebih rendah jika dibandingkan dengan premium. Tetapi angka oktan yang dimiliki ethanol lebih tinggi dari premium dan dapat digunakan untuk kompresi mesin yang lebih tinggi.

Tabel 2.3 Properti Alkohol

(Kristanto, 2015:78)

\begin{tabular}{|l|c|c|c|}
\hline & Isoktan & Methanol & Ethanol \\
\hline Formula & $\mathrm{C}_{8} \mathrm{H}_{8}$ & $\mathrm{CH}_{3} \mathrm{OH}$ & $\mathrm{C}_{2} \mathrm{H}_{5} \mathrm{OH}$ \\
Berat molekul & 114,224 & 32,042 & 46,07 \\
Karbon/hidrogen (berat) & 5,25 & 3,0 & 4,0 \\
\% karbon (berat) & 84,0 & 37,5 & 52,17 \\
\% hidrogen (berat) & 16,0 & 12,5 & 13,4 \\
\% oksigen (berat) & 0 & 50,0 & 34,78 \\
Titik didih @ 1 atm ${ }^{0} \mathrm{C}$ & 99,239 & 64,5 & 78,40 \\
Titik beku @ 1 atm ${ }^{0} \mathrm{C}$ & $-107,378$ & $-97,778$ & $-80,00$ \\
Kerapatan @ 15,5 ${ }^{\circ} \mathrm{C}$ lb/gal Viskositas @ & 5,795 & 6,637 & 6,63 \\
$20^{\circ} \mathrm{C} / 1$ atm, centipois & 0,503 & 0,596 & 1,20 \\
Kalor spesifik @ 25 ${ }^{\circ} \mathrm{C} / 1$ atm, BTU/lb & 0,5 & 0,6 & 0,6 \\
Kalor penguapan, @ titik didih/1 atm, & 116,69 & 473,0 & 361,0 \\
BTU/lb & 132,0 & 503,3 & - \\
Kalor penguapan/1 atm kalor & 15,13 & 6,463 & 9,0 \\
Kalor pembakaran bawah Stoikiometri lb & 100 & 106 & 105 \\
udara & $-42,778$ & 11,112 & 12,778 \\
RON & - & 5 & 8 \\
Temperatur nyala api, 20 ${ }^{\circ} \mathrm{C}, \mathrm{kJ} / \mathrm{kg}$ & & & \\
Bilangan cetana & & & \\
& & & \\
\hline
\end{tabular}

\section{Nilai Oktan}

Nilai oktan adalah indikator dari bahan bakar untuk mesin pembakaran mesin bensin, yang menunjukkan seberapa kuat bahan bakar tersebut tidak terbakar dengan sendirinya (Sarjono dan Putra, 2013:5). Angka oktan yang dimiliki oleh ethanol lebih tinggi dari pada pertalite. Jika campuran udara dan bahan bakar terbakar sebelum waktunya akan menimbulkan fenomena knocking yang memiliki potensi untuk menurunkan daya mesin, bahkan mampu menimbulkan kerusakan serius pada komponen mesin (Handayani, 2007:100).

Bensin dengan bilangan oktan yang tinggi memiliki periode penundaan yang panjang. Oleh karena itu lebih sesuai untuk motor bensin dengan perbandingan kompresi yang tinggi. Dengan adanya bensin dengan bilangan oktan yang tinggi hambatan yang disebabkan oleh detonasi berangsur-angsur dapat diatasi (Arismunandar, 1977:85).

\section{Nilai Kalor}

Nilai kalor atau heating value dari bahan bakar merupakan ukuran panas dari reaksi pada volume konstan dan keadaan standar untuk pembakaran sempurna satu mol pada bahan bakar (Muchammad, 2010:31). Nilai kalor pada ethanol sekitar 67\% nilai kalor bensin, hal ini disebabkan oleh adanya oksigen dalam struktur ethanol (Handayani, 2007:100).

Nilai kalor pada bahan bakar terdiri dari:

\section{Nilai Kalor Atas}

Nilai kalor atas atau highest heating value (HHV) atau gross heating value (GHV) merupakan nilai kalor yang diperoleh dari pembakaran $1 \mathrm{~kg}$ bahan bakar dengan memperhitungkan panas kondensasi uap, jenis 
air yang dihasilkan dari pembakaran berwujud cair (Napitupulu, 2006:60).

\section{Nilai Kalor Bawah}

Nilai kalor bawah atau lowest heating value (LHV) merupakan nilai kalor yang diperoleh dari pembakaran $1 \mathrm{~kg}$ bahan bakar tanpa memperhitungkan panas kondensasi uap, jenis air yang dihasilkan dari pembakaran berwujud gas atau uap (Napitupulu, 2006:60).

Jika suatu bahan bakar diketahui nilai kalor atasnya atau highest heating value (HHV), maka untuk menghitung nilai kalor bawah atau lowest heating value (LHV) dapat dihitung dengan persamaan: $\mathrm{LHV}=\mathrm{HHV}$ - $3240(\mathrm{~kJ} / \mathrm{kg})$

\section{Pembakaran pada Motor Bensin}

Pembakaran pada motor bensin diawali oleh percikan bunga api dari busi yang terjadi beberapa derajat poros engkol sebelum torak mencapai titik mati atas (Wiratmaja, 2010:18). Proses pembakaran pada suatu mesin terjadi dalam beberapa tingkatan yang digambarkan dalam grafik dengan hubungan antara tekanan dan perjalanan poros engkol. Berikut merupakan grafik tingkatan pembakaran:

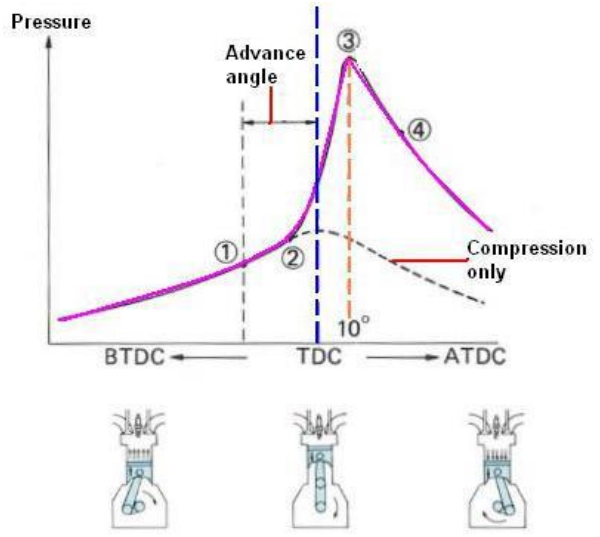

Gambar 2.1 Grafik Pembakaran Motor Bensin. (http://slideplayer.info/slide/4095828/)

Keterangan:

1 = saat pengapian

$2=$ mulai pembakaran bahan bakar

$3=$ tekanan maksimum pembakaran

$4=$ akhir pembakaran

Berdasarkan Gambar 2.1 campuran bahan bakar dengan udara yang dihisap lalu dikompresikan. Tekanan dan temperatur di dalam ruang bakar mengalami peningkatan selama langkah kompresi dan campuran bahan bakar dengan udara akan sangat mudah untuk terbakar. Sebelum piston mencapai titik mati atas (TMA), terjadi penyalaan bunga api oleh busi sehingga terjadi proses pembakaran yang mengakibatkan tekanan dan temperatur akan semakin tinggi. Puncaknya terjadi setelah piston melewati TMA. Hal ini terjadi agar piston terdorong menuju ke titik mati bawah (TMB) dengan tekanan yang tinggi hingga akhir pembakaran. Pada saat piston bergerak dari TMA ke TMB tekanan perlahan akan menurun.

Secara umum proses pembakaran pada motor bensin dibedakan menjadi dua bagian yaitu:

1. Pembakaran sempurna

Pembakaran sempurna adalah pembakaran dimana semua unsur yang dapat terbakar di dalam bahan bakar akan membentuk gas $\mathrm{CO} 2$ dan $\mathrm{H} 2 \mathrm{O}$, sehingga tidak ada lagi bahan bakar yang tersisa (Wiratmaja, 2010:18).

2. Pembakaran tidak sempurna

Pembakaran yang tidak sempurna akan menimbulkan gejala mesin yang disebut dengan detonasi. Hal tersebut terjadi karena pada proses pembakaran yang tidak serentak pada saat langkah kompresi belum berakhir atau saat busi belum memercikkan bunga api dan ditandai dengan adanya pengapian sendiri yang muncul mendadak pada bagian akhir campuran (Wiratmaja, 2010:18). Dengan kata lain campuran bahan bakar yang sudah terbakar akan menekan campuranbahan bakar yang belum terbakar, sehingga temperaturnya naik dan menyala dengan sendirinya.

\section{Torsi dan Daya}

Torsi adalah indikator baik dari ketersedian mesin untuk kerja. Torsi didefinisikan sebagai gaya yang bekerja pada jarak momen dan apabila dihubungkan dengan kerja dapat ditunjukan. Daya adalah besar usaha yang dihasilkan oleh mesin tiap satuan waktu, didefinisikan sebagai laju kerja mesin, ditunjukkan dengan persamaan (Heywood,1988). Dalam hal ini daya secara normal diukur dalam $\mathrm{kW}$, tetapi satuan HP masih digunakan juga, dimana :

$1 \mathrm{HP}=0,7457 \mathrm{~kW}$

$1 \mathrm{~kW}=1,341 \mathrm{HP}$

Torsi

Torsi adalah ukuran kemampuan mesin untuk melakukan kerja, jadi torsi adalah suatu energi. Besaran torsi adalah besaran turunan yang biasa digunakan untuk menghitung energi yang dihasilkan dari benda yang berputar pada porosnya. Adapun perumusan dari torsi adalah sebagai berikut. Apabila suatu benda berputar dan mempunyai besar gaya sentrifugal sebesar F, benda berputar pada porosnya dengan jari-jari sebesar $\mathrm{b}$, dengan data tersebut torsinya adalah:

$$
\mathrm{T}=\mathrm{F} \times \mathrm{d}(\mathrm{N} . \mathrm{m})
$$

dimana:

$\mathrm{T}$ : Torsi benda berputar (N.m)

$\mathrm{F}$ : adalah gaya dari benda yang berputar $(\mathrm{N})$ 
d : adalah jarak benda ke pusat rotasi (m)

Karena adanya torsi inilah yang menyebabkan benda berputar terhadap porosnya, dan benda akan berhenti apabila ada usaha melawan torsi dengan besar sama dengan arah yang berlawanan.

Daya

Daya motor merupakan salah satu parameter dalam menentukan performa motor. Pengertian dari daya itu adalah besarnya kerja motor selama kurun waktu tertentu sebagai satuan daya dipilih watt.

Untuk menghitung besarnya daya motor 4 langkah digunakan rumus :

$$
P=\tau \times \omega \times 2 \pi / 33.000
$$

Dimana satuan yang digunakan adalah:

Daya P dalam horsepower (hp)

Torsi $\tau$ dalam pound feet (lbf.ft)

Kecepatan sudut $\omega$ dalam Revolution Per Minutes (RPM)

$1 \mathrm{~nm}: 0.73$ lbf.ft

Dari rumus di atas daya motor dapat diketahui besarnya setelah diketahui berapa besar torsi $(\mathrm{T})$ dan putaran mesin (n) yang dihasilkan motor itu. Dalam penelitian ini untuk mengukur daya motor digunakan alat Dynamometer.

\section{Pembakaran Motor 4 Langkah}

Motor bakar empat langkah adalah mesin pembakaran dalam, yang dalam satu kali siklus pembakaran akan mengalami empat langkah piston. Sekarang ini, mesin pembakaran dalam pada mobil, sepeda motor, truk, pesawat terbang, kapal, alat berat dan sebagainya, umumnya menggunakan proses siklus motor empat langkah. Proses siklus motor empat langkah dilakukan oleh gerak piston dalam silinder tertutup, yang bersesuaian dengan pengtauran gerak kerja katup isap dan katup buang di setiap langkah kerjanya. Proses yang terjadi meliputi langkah hisap (pemasukan), kompresi, tenaga dan langkah buang.

\section{Cara Kerja Mesin 4 Tak ( 4 Langkah )}

\section{Langkah Penghisapan}

Piston bergerak dari titik mati atas (TMA) menuju titik mati bawah (TMB). Katup isab dibuka dan katup buang ditutup, karena terjadi tekanan negative/vacuum dalam silinder, selanjutnya campuran udara dan bahan terisap masuk melalui katup isap, untuk mengisi ruang silinder.

\section{Langkah Kompresi}

Piston bergerak dari titik mati bawah (TMB) menuju titik mati atas (TMA). Katup isap dan katup buang ditutup. Pada proses ini campuran bahan bakar dan udara ditekan atau kompresi, akibatnya tekanan dan temperaturnya naik sehingga akan memudahkan proses pembakaran.

\section{Langkah Kerja}

Piston bergerak dari titik mati atas (TMA) menuju titik mati bawah (TMB). Katup isap dan katup buang ditutup. Sesaat piston menjelang titik mati atas, busi pijar menyalakan percikan api seketika campuran bahan bakar dan udara terbakar secara cepat berupa ledakan. Dengan terjadinya ledakan, maka menghasilkan tekanan sangat tinggi untuk mendorong piston ke bawah, sebagai tenaga atau usaha yang dihasilkan mesin.

\section{Langkah Buang}

Piston bergerak dari titik mati bawah (TMB) menuju titik mati atas (TMA). Katup isap ditutup dan katup buang dibuka. Pada proses ini gas yang telah terbakar dibuang oleh dorongan piston ke atas dan selanjutnya mengalir melalui katup buang. Pada posisi ini poros engkol telah berputar dua kali putaran penuh dalam satu siklus dari empat langkah.
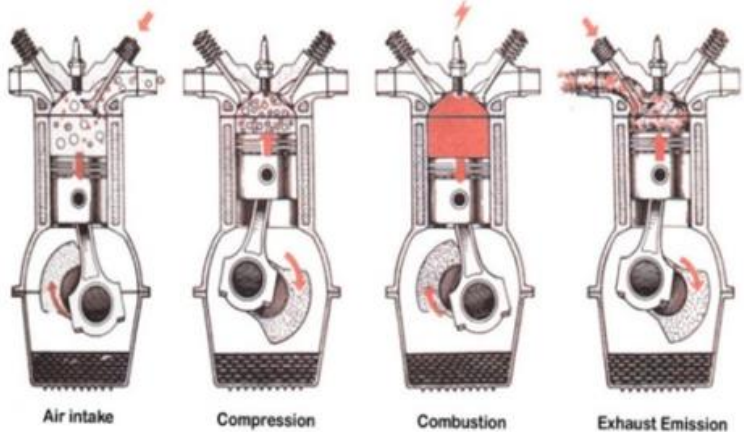

Gambar 2.2 Prinsip kerja motor 4 langkah

\section{Hipotesis}

Dari pembahasan dalam kerangka berfikir dapat disimpulkan bahwa campuran pertalite dan ethanol akan menurunkan daya dan torsi pada motor. Sehingga hipotesis awal yaitu:

1. Penambahan ethanol pada pertalite berpengaruh terhadap daya dan torsi pada mesin matic.

2. Penambahan ethanol pada pertalite dapat bekerja optimal di bawah volume $20 \%$.

\section{METODOLOGI PENELITIAN Metode Penelitian}

Metode penelitian yang dilakukan adalah metode eksperimental. Metode eksperimental adalah metode yang digunakan untuk menguji suatu perlakuan atau desain baru dengan cara membandingkan sebelum perlakuan dan sesudah perlakuan sebagai pengontrolnya. 


\section{Waktu dan Tempat Penelitian}

Penelitian ini dilakukan di Lab Pengujian Performa Mesin Universitas Negeri Surabaya pada hari Kamis, 10 Januari 2019, penelitian ini yang dilakukan yaitu mengenai uji daya dan torsi.

Tahap awal penelitian dan selanjutnya mengumpulkan data-data untuk mencari sebuah rumusan masalah pada sebuah bidang untuk di analisa. Selanjutnya menyiapkan bahan yang digunakan dalam sebuah penelitian. Proses atau tahapan penelitian dimana bahan penelitian yang digunakan akan diteruskan dalam sebuah proses pengujian, untuk menemukan hasil dan pembahasan dalam penelitian sampai pada tahap akhir yaitu penyelesaian.

\section{Bahan dan Alat Penelitian}

Bahan Penelitian

Bahan yang digunakan dalam penelitian ini adalah:

1. BBM yang digunakan ini ialah pertalite dengan nilai oktan 90.

2. Ethanol $\left(\mathrm{C}_{2} \mathrm{H}_{5} \mathrm{OH}\right)$ dengan kadar $70 \%$ dan volume $10 \%, 20 \%$

\section{Alat Penelitian}

Alat yang digunakan dalam penelitian ini adalah:

1. Tachometer

2. Selang Bensin

3. Stopwatch

4. Dynamometer

5. Burret (Bejana)

6. Mesin 4 langkah yang dengan spesifikasi sebagai berikut :

7. Mesin 4 langkah yang dengan spesifikasi sebagai berikut :

Tipe mesin pendinginan cairan

Diameter x langkah

Volume langkah

Perbandingan kompresi

Daya maksimum

Torsi maksimum

Kopling

Starter

Busi

\section{CPR7EA-9}

Sistem Bahan Bakar

Kapasitas tangki

Kapasitas minyak

Transmisi

Aki
Sistem pengapian

Baterai

Panjang $\mathrm{x}$ lebar $\mathrm{x}$ tinggi

$\mathrm{mm}$

Jarak sumbu roda

Jarak terendah ke tanah

Berat kosong

Tipe rangka

Tipe suspensi depan

Tipe suspensi belakang shockbreaker tunggal

Ukuran ban depan

Ukuran ban belakang

Rem depan

dengan piston tunggal

Rem belakang

Sistem Pengereman

Brake System (CBS)

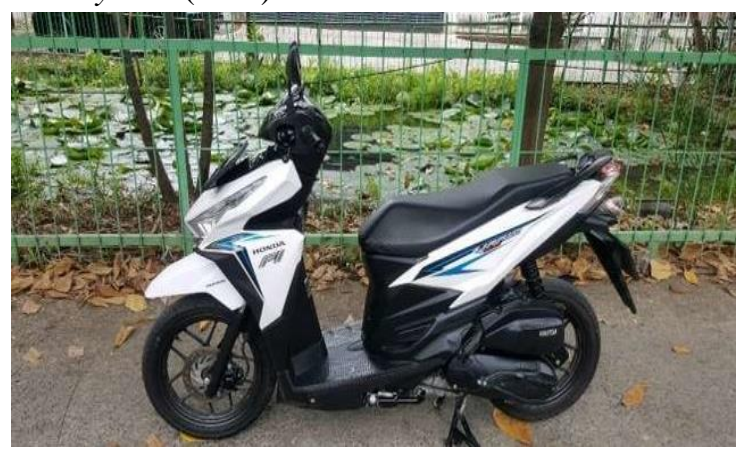

Gambar 3.1 Sepeda Motor Matic 125cc

\section{Teknik Pengumpulan Data}

1. Referensi

Kajian teori dalam buku sebagai penunjang dalam melaksanakan penelitian. Literatur yang digunakan adalah yang berhubungan dengan bahan bakar berupa pertalite

2. Pengujian Kondisi Stasioner

Data yang diperoleh dari hasil pengujian yaitu daya dan torsi dimasukkan kedalam tabel-tabel yang telah disediakan hal ini bertujuan untuk mengetahui hasil yang diperoleh selama pengujian berlangsung.

Identifikasi Variabel

Dari pengertian tersebut secara garis besar variabel dalam penelitian ini ada dua variabel, yang secara lengkap dijelaskan sebagai berikut:

\section{Variabel Terikat}

Variabel terikat yaitu variabel yang ditentukan oleh peneliti sebelum melakukan penelitian, variabel terikat yang digunakan adalah sebagai berikut: 


\section{Variasi Perlakuan}

Variasi perlakuan yang akan dilakukan dalam penelitian ini adalah:

1. Pengujian pada motor matic $125 \mathrm{cc}$ dengan menggunakan bahan bakar pertalite.

2. Pengujian pada motor matic $125 \mathrm{cc}$ dengan menggunakan campuran pertalite dengan ethanol.

\section{Putaran Mesin}

Tester menginginkan putaran yang berubah sesuai dengan kemampuan mesin mulai dari kecepatan 3000 rpm sampai dengan kecepatan 6000 rpm.

\section{Variabel Bebas}

Variabel bebas merupakan variabel yang besarnya tidak dapat ditentukan peneliti, tetapi besarnya tergantung pada variabel terikatnya. Penelitian ini bertjuan untuk memperoleh hasil unjuk kerja maksimal dari mesin motor matic $125 \mathrm{cc}$, dengan menganalisa data-data yang meliputi:

1. Waktu atau $\mathrm{t}$ (detik)

2. Daya (hp)

3. Torsi (nm)

\section{Prosedur Penelitian}

Setelah proses penempatan dan penyusunan peralatan dan juga motor ingin diuji telah selesai dilakukan, maka setelah itu dilakukan pengecekan terhadap alat dynamometer.

Pelaksanaan dari penelitian ini dibagi menjadi dua tahap yaitu:

\section{Tahap Persiapan Penelitian}

1. Mempersiapkan alat dan bahan untuk penelitian

2. Memverifikasi alat ukur bahan bakar

3. Melakukan tune up mesin pada objek penelitian.

4. Mempersiapkan bahan bakar pertalite di dalam gelas ukur.

5. Mempersiapkan perlengkapan alat dan instrumen pengujian yang akan digunakan.

\section{Tahap Pengujian}

Tahapan dalam proses pengujian dapat diperinci sebagai berikut :

1. Mengisikan bahan bakar dan mengatur volume pada tabung bejana.

2. Menghidupkan mesin.

3. Memanaskan mesin motor sehingga mendekati suhu kerja selama 2-3 menit.

4. Memulai pengujian atau proses data daya dan torsi dalam hitungan waktu 10 detik.

5. memulai pengujian dan pengambilan data dengan alat tachnometer dengan range putaran $3000 \mathrm{rpm}$, $3500 \mathrm{rpm}, 4000 \mathrm{rpm}, 4500 \mathrm{rpm}, 5000 \mathrm{rpm}, 5500$ rpm, dan $6000 \mathrm{rpm}$

6. Pengujian dilakukan sebanyak 3 kali pengulangan.
7. Penambahan Ethanol.

8. Mengulangi langkah 1-4 secara berurutan.

9. Perolehan data.

\section{Diagram Alir Penelitian}

Diagram alir penelitian yang dilakukan dengan prosedur adalah sebagai berikut seperti pada gambar di bawah ini.

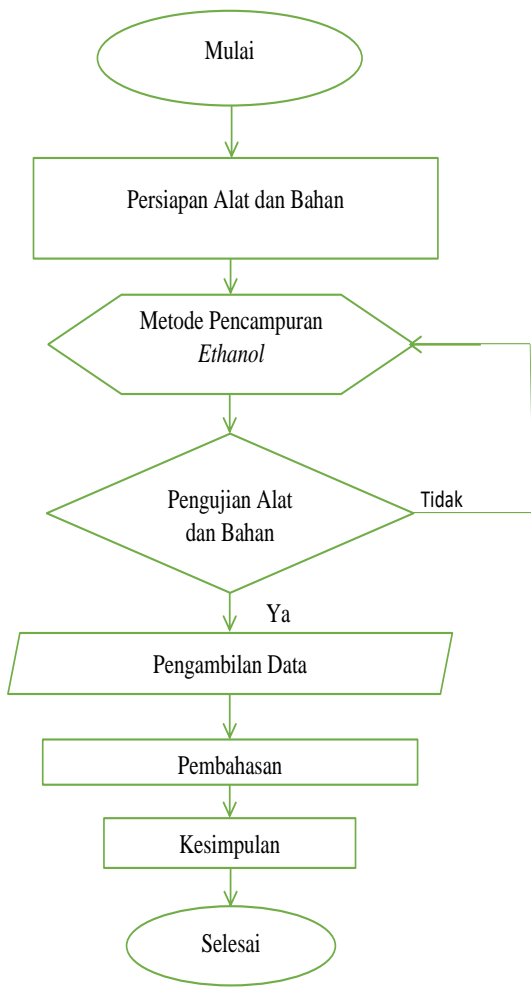

Gambar 3.2 Diagram Alir Penelitian

\section{HASIL DAN PEMBAHASAN}

Uji Daya Standart

Pengambilan data dilakukan sebanyak 3 kali dengan menghitung besar daya yang dihasilkan pada putaran mesin 3000, 3500, 4000, 4500, 5000, 5500 dan $6000 \mathrm{rpm}$. Untuk mengetahui berapa besar daya yang dihasilkan pada motor 4 matic 125 cc dalam kondisi standart dan dengan campuran ethanol. Berikut adalah data hasil percobaan yang dilakukan dalam bentuk tabel :

Tabel 4.1 Uji RPM terhadap Daya Standart

\begin{tabular}{|c|c|c|c|c|}
\hline \multirow{2}{*}{$\begin{array}{c}\text { Putaran } \\
\text { Mesin }\end{array}$} & \multicolumn{3}{|c|}{ Daya } & \multirow{2}{*}{$\begin{array}{c}\text { Rata - } \\
\text { Rata }\end{array}$} \\
\cline { 2 - 4 } & Uji 1 & Uji 2 & Uji 3 & \\
\hline 3000 & 2,0 & 4,0 & 1,8 & 2,6 \\
\hline 3500 & 5,4 & 6,2 & 5,0 & 5,5 \\
\hline 4000 & 6,8 & 7,2 & 6,5 & 6,8 \\
\hline 4500 & 7,8 & 8,0 & 7,3 & 7,7 \\
\hline 5000 & 8,2 & 8,2 & 8,2 & 8,2 \\
\hline
\end{tabular}




\begin{tabular}{|l|l|l|l|l|}
\hline 5500 & 8,3 & 8,3 & 8,2 & 8,3 \\
\hline 6000 & 8,4 & 8,2 & 8,2 & 8,3 \\
\hline
\end{tabular}

Dari tabel diatas dapat dilihat daya pada motor matic relatif berbeda dari setiap variasi rpm-nya, Naik dan turunnya daya disetiap 3000, 3500, 4000, 4500, 5000, 5500, dan 6000 rpm-nya berkisar antara 0,1 - 2, 5 HP. kenaikan daya tertinggi yaitu pada $3500 \mathrm{rpm}$ sebesar 2,9 HP.

Untuk lebih jelasnya dapat dilihat pada grafik dibawah ini :

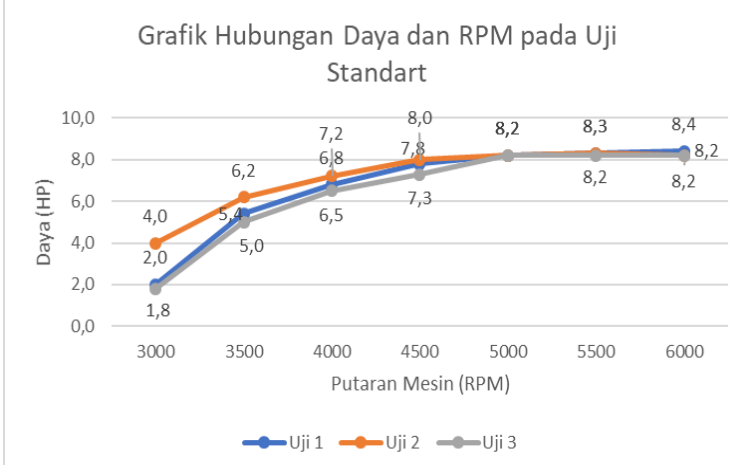

Gambar 4.1 Grafik hubungan Daya dan RPM pada Uji Standart

\section{Uji Daya dengan campuran ethanol $10 \%$}

Selanjutnya dilakukan pengujian dengan pencampuran pertalite $90 \%$ dan ethanol $10 \%$ pada motor matic $125 \mathrm{cc}$, sebagai data pembanding dengan uji daya standart.

Berikut adalah tabel hasil pengujian pada motor matic 125cc:

Tabel 4.2 Uji RPM terhadap Daya dengan Campuran ethanol $10 \%$

\begin{tabular}{|c|c|c|c|c|}
\hline \multirow{2}{*}{$\begin{array}{c}\text { Putaran } \\
\text { Mesin }\end{array}$} & \multicolumn{3}{|c|}{ Daya } & Rata-Rata \\
\cline { 2 - 4 } & Uji 1 & Uji 2 & Uji 3 & \\
\hline 3000 & 2,2 & 3,1 & 2,7 & 2,6 \\
\hline 3500 & 4,8 & 6,0 & 5,6 & 5,4 \\
\hline 4000 & 6,7 & 7,1 & 6,9 & 6,9 \\
\hline 4500 & 7,8 & 8,1 & 7,8 & 7,9 \\
\hline 5000 & 8,3 & 8,4 & 8,3 & 8,3 \\
\hline 5500 & 8,3 & 8,4 & 8,4 & 8,4 \\
\hline 6000 & 8,5 & 8,4 & 8,4 & 8,4 \\
\hline
\end{tabular}

Dari tabel diatas dapat dilihat daya pada motor matic relatif berbeda dari setiap variasi rpm-nya, Naik dan turunnya daya disetiap 3000, 3500, 4000, 4500, 5000, 5500, dan 6000 rpm-nya berkisar antara 0,1 -2,8 HP. kenaikan daya tertinggi yaitu pada $3500 \mathrm{rpm}$ sebesar 2,8 HP.
Untuk lebih jelasnya dapat dilihat pada grafik dibawah ini :

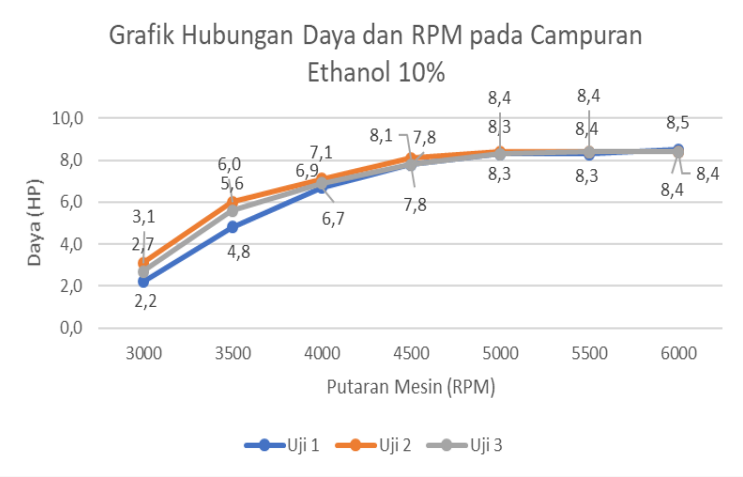

Gambar 4.2 Grafik hubungan Daya dan RPM pada campuran ethanol $10 \%$

\section{Uji Daya dengan campuran ethanol 20\%}

Selanjutnya dilakukan pengujian dengan pencampuran pertalite $80 \%$ dan ethanol $20 \%$ pada motor matic $125 \mathrm{cc}$, sebagai data pembanding dengan uji daya standart dan campuran ethanol $10 \%$. Berikut adalah tabel hasil pengujian pada motor matic $125 \mathrm{cc}$ :

Tabel 4.3 Uji RPM terhadap Daya dengan Campuran ethanol $20 \%$

\begin{tabular}{|c|c|c|c|c|}
\hline \multirow{2}{*}{$\begin{array}{c}\text { Putaran } \\
\text { Mesin }\end{array}$} & \multicolumn{3}{|c|}{ Daya } & \multirow{2}{*}{$\begin{array}{c}\text { Rata- } \\
\text { Rata }\end{array}$} \\
\cline { 2 - 4 } & Uji 1 & Uji 2 & Uji 3 & \\
\hline 3000 & 4,0 & 3,7 & 3,5 & 3,7 \\
\hline 3500 & 6,2 & 5,9 & 3,5 & 5,2 \\
\hline 4000 & 7,0 & 7,2 & 6,1 & 6,8 \\
\hline 4500 & 8,0 & 7,9 & 7,1 & 7,7 \\
\hline 5000 & 8,4 & 8,4 & 8,1 & 8,3 \\
\hline 5500 & 8,3 & 8,4 & 8,1 & 8,3 \\
\hline 6000 & 8,5 & 8,3 & 8,2 & 8,3 \\
\hline
\end{tabular}

Dari tabel diatas dapat dilihat daya pada motor matic relatif berbeda dari setiap variasi rpm-nya, Naik dan turunnya daya disetiap 3000, 3500, 4000, 4500, 5000, 5500, dan 6000 rpm-nya berkisar antara 0,1 - 1,6 HP. kenaikan daya tertinggi yaitu pada $4000 \mathrm{rpm}$ sebesar 1,6 HP. 
Untuk lebih jelasnya dapat dilihat pada grafik dibawah ini :

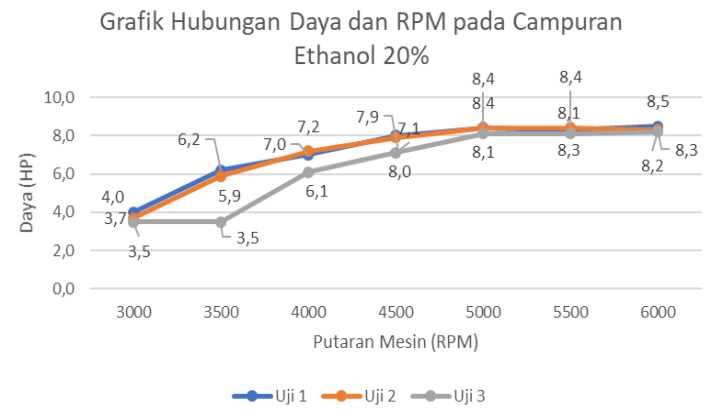

Gambar 4.3 Grafik hubungan Daya dan RPM pada campuran ethanol $20 \%$

Perbandingan Uji Daya pada Motor Matic Tak 125 cc Standart dan dengan Campuran Ethanol

Untuk mempermudah proses analisa data perbandingan antara uji daya pada motor matic $125 \mathrm{cc}$ Standart dan dengan penambahan Ethanol $10 \%$ dan $20 \%$ kami buat dalam bentuk grafik sebagai berikut :

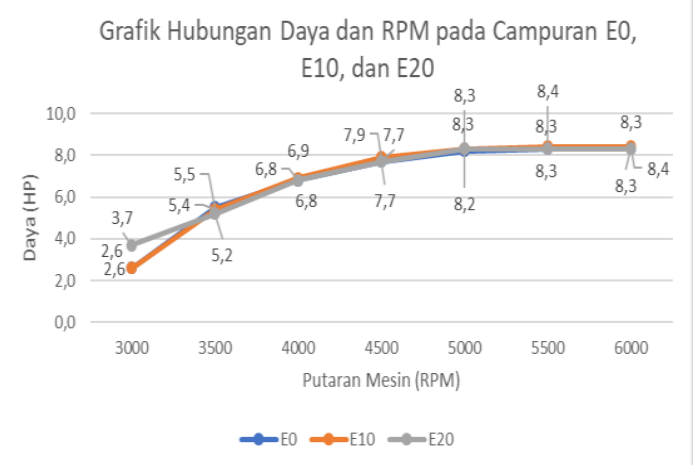

Gambar 4.4 Grafik Hubungan Daya dan RPM pada Campuran E0, E10, dan E20

\section{Uji Torsi Standart}

Pengambilan data dilakukan sebanyak 3 kali dengan menghitung besar torsi yang dihasilkan pada putaran mesin 3000, 3500, 4000, 4500, 5000, 5500 dan $6000 \mathrm{rpm}$. Untuk mengetahui berapa besar torsi yang dihasilkan pada motor matic 125 cc dalam kondisi standart dan dengan campuran ethanol.

Berikut adalah data hasil percobaan yang dilakukan dalam bentuk tabel :

Tabel 4.4 Uji RPM terhadap Torsi Standart

\begin{tabular}{|c|c|c|c|c|}
\hline \multirow{2}{*}{$\begin{array}{c}\text { Putaran } \\
\text { Mesin }\end{array}$} & \multicolumn{3}{|c|}{ Torsi } & \multirow{2}{*}{$\begin{array}{l}\text { Rata- } \\
\text { Rata }\end{array}$} \\
\hline & Uji 1 & Uji 2 & Uji 3 & \\
\hline 3000 & 4,85 & 5,90 & 9,61 & 6,78 \\
\hline 3500 & 10,92 & 10,96 & 12,76 & 11,54 \\
\hline 4000 & 12,08 & 12,11 & 12,93 & 12,37 \\
\hline 4500 & 12,29 & 12,35 & 12,65 & 12,43 \\
\hline
\end{tabular}

\begin{tabular}{|c|c|c|c|c|}
\hline 5000 & 11,65 & 11,63 & 11,62 & 11,63 \\
\hline 5500 & 10,77 & 10,57 & 10,75 & 10,70 \\
\hline 6000 & 9,93 & 9,84 & 9,66 & 9,81 \\
\hline
\end{tabular}

Dari tabel diatas dapat dilihat torsi pada motor matic relatif berbeda dari setiap variasi rpm-nya, Naik dan turunnya daya disetiap 3000, 3500, 4000, 4500, 5000, 5500, dan 6000 rpm-nya berkisar antara 0,9 $4,74 \mathrm{Nm}$. kenaikan daya tertinggi yaitu pada $3500 \mathrm{rpm}$ sebesar 4,74 Nm.

Untuk lebih jelasnya dapat dilihat pada grafik dibawah ini :

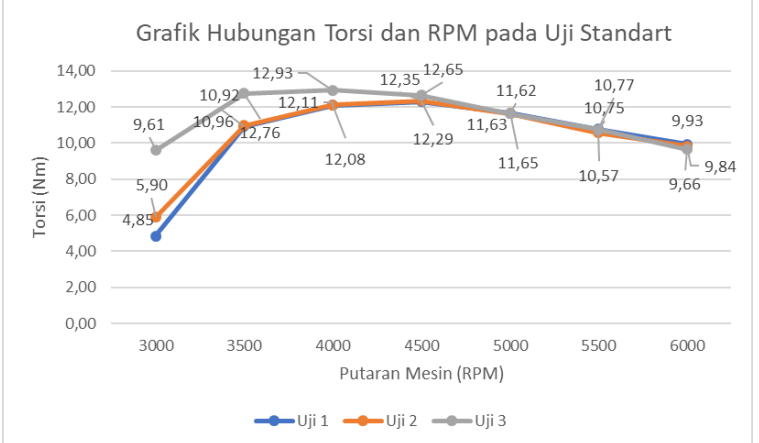

Gambar 4.5 Grafik hubungan Torsi dan RPM pada Uji

\section{Standart}

\section{Uji Torsi dengan campuran ethanol $10 \%$}

Selanjutnya dilakukan pengujian dengan pencampuran pertalite $90 \%$ dan ethanol $10 \%$ pada motor matic $125 \mathrm{cc}$, sebagai data pembanding dengan uji Torsi standart.

Berikut adalah tabel hasil pengujian pada motor matic $125 \mathrm{cc}$ :

Tabel 4.5 Uji RPM terhadap Torsi dengan Campuran ethanol $10 \%$

\begin{tabular}{|c|c|c|c|c|}
\hline \multirow{2}{*}{$\begin{array}{c}\text { Putaran } \\
\text { Mesin }\end{array}$} & \multicolumn{3}{|c|}{ Torsi } & $\begin{array}{c}\text { Rata- } \\
\text { Rata }\end{array}$ \\
\cline { 2 - 4 } & Uji 1 & Uji 2 & Uji 3 & \\
\hline 3000 & 7,30 & 7,41 & 6,34 & 7,02 \\
\hline 3500 & 9,66 & 12,19 & 11,41 & 11,09 \\
\hline 4000 & 12,04 & 12,62 & 12,35 & 12,33 \\
\hline 4500 & 12,37 & 12,81 & 12,38 & 12,52 \\
\hline 5000 & 11,79 & 11,90 & 11,79 & 11,82 \\
\hline 5500 & 10,76 & 10,88 & 10,81 & 10,81 \\
\hline 6000 & 9,97 & 9,94 & 9,88 & 9,93 \\
\hline
\end{tabular}

Dari tabel diatas dapat dilihat torsi pada motor matic relatif berbeda dari setiap variasi rpm-nya, Naik dan turunnya daya disetiap 3000, 3500, 4000, 4500, 5000, 5500, dan 6000 rpm-nya berkisar antara 0,194,07 Nm. kenaikan daya tertinggi yaitu pada $3500 \mathrm{rpm}$ sebesar 4,07 Nm. 
Untuk lebih jelasnya dapat dilihat pada grafik dibawah ini :

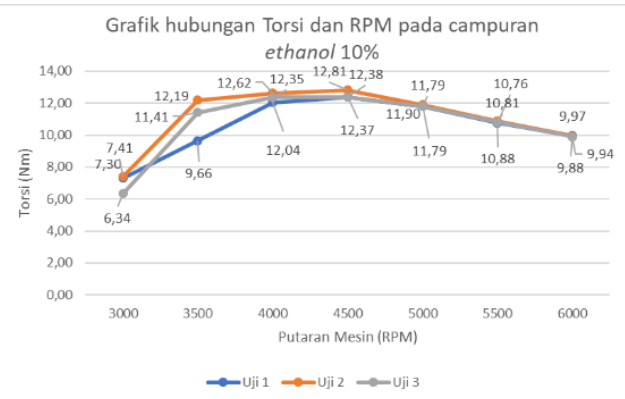

Gambar 4.6 Grafik hubungan Torsi dan RPM pada campuran ethanol $10 \%$

Uji Torsi dengan campuran ethanol $20 \%$

Selanjutnya dilakukan pengujian dengan pencampuran pertalite $90 \%$ dan ethanol $20 \%$ pada motor matic $125 \mathrm{cc}$, sebagai data pembanding dengan uji Torsi standart dan campuran ethanol 10\%. Berikut adalah tabel hasil pengujian pada motor matic $125 \mathrm{cc}$ :

Tabel 4.6 Uji RPM terhadap Torsi dengan Campuran ethanol $20 \%$

\begin{tabular}{|c|c|c|c|c|}
\hline \multirow{2}{*}{$\begin{array}{c}\text { Putaran } \\
\text { Mesin }\end{array}$} & \multicolumn{3}{|c|}{ Torsi } & \multirow{2}{*}{$\begin{array}{c}\text { Rata- } \\
\text { Rata }\end{array}$} \\
\cline { 2 - 4 } & Uji 1 & Uji 2 & Uji 3 & \\
\hline 3000 & 9,57 & 8,70 & 6,34 & 8,20 \\
\hline 3500 & 12,54 & 12,13 & 7,05 & 10,57 \\
\hline 4000 & 12,45 & 12,72 & 10,86 & 12,01 \\
\hline 4500 & 12,62 & 12,54 & 11,28 & 12,14 \\
\hline 5000 & 11,90 & 11,91 & 11,46 & 11,75 \\
\hline 5500 & 10,77 & 10,82 & 10,50 & 10,69 \\
\hline 6000 & 10,10 & 9,79 & 9,65 & 9,84 \\
\hline
\end{tabular}

Dari tabel diatas dapat dilihat torsi pada motor matic relatif berbeda dari setiap variasi rpm-nya, Naik dan turunnya daya disetiap 3000, 3500, 4000, 4500, 5000, 5500, dan 6000 rpm-nya berkisar antara 0,13 $2.37 \mathrm{Nm}$. kenaikan daya tertinggi yaitu pada $3500 \mathrm{rpm}$ sebesar 2,37 Nm.

Untuk lebih jelasnya dapat dilihat pada grafik dibawah ini :

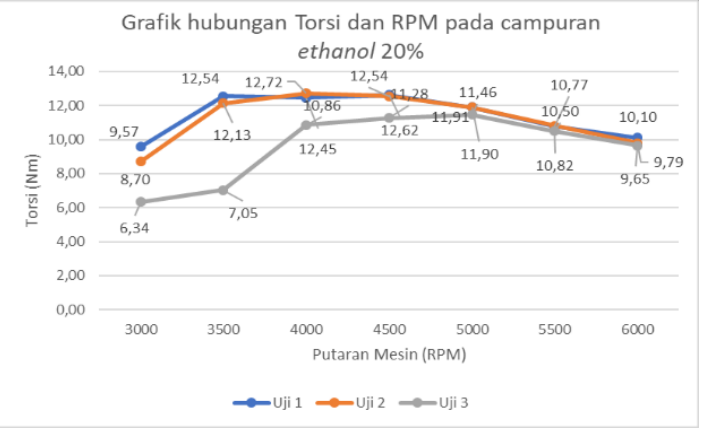

Gambar 4.7 Grafik hubungan Torsi dan RPM pada campuran ethanol $20 \%$
Perbandingan Uji Torsi pada Motor Matic Tak 125 cc Standart dan dengan Campuran Ethanol

Untuk mempermudah proses analisa data perbandingan antara uji torsi pada motor matic $125 \mathrm{cc}$ Standart dan dengan penambahan Ethanol $10 \%$ dan $20 \%$ kami buat dalam bentuk grafik sebagai berikut :

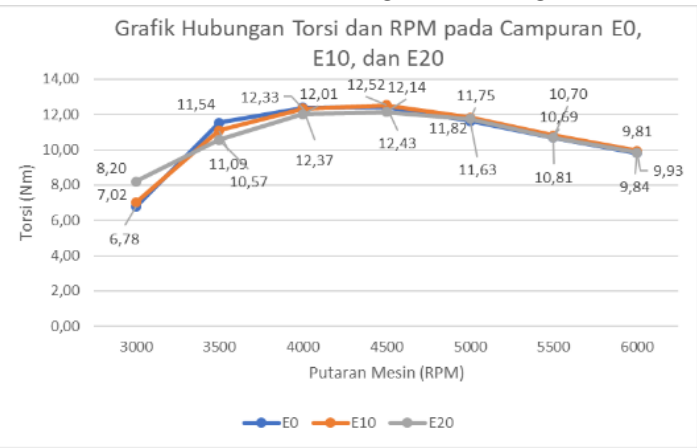

Gambar 4.8 Grafik Perbandingan E0, E10, dan E20 terhadap uji torsi

\section{Pembahasan}

Uji Daya

Untuk mempermudah proses analisa data perbandingan antara uji daya pada motor matic $125 \mathrm{cc}$ Standart dan dengan penambahan Ethanol 10\% dan $20 \%$ kami buat dalam bentuk tabel sebagai berikut :

Tabel 4.7 Perbandingan Uji Daya Motor Matic 125cc

\begin{tabular}{|c|c|c|c|}
\hline RPM & Standart & E10 & E20 \\
\hline 6000 & 8,3 & & \\
\hline 6000 & & 8,4 & \\
\hline 6000 & & & 8,3 \\
\hline
\end{tabular}

Untuk lebih jelasnya, berikut merupakan grafik Perbandingan Uji Daya Motor Matic 125cc:

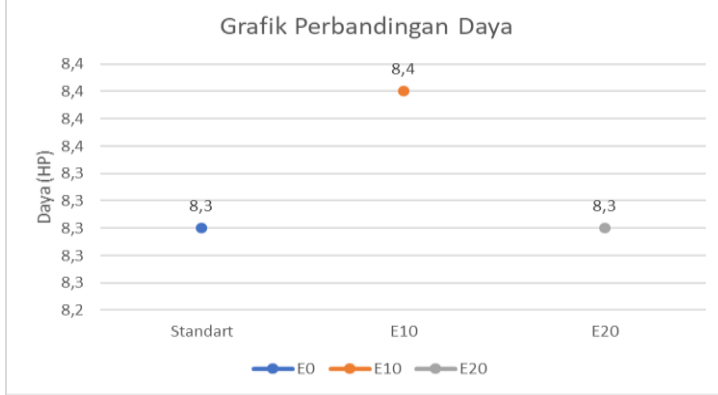

Gambar 4.9 Grafik Perbandingan Daya

\section{Uji Torsi}

Untuk mempermudah proses analisa data perbandingan antara uji Torsi pada motor matic $125 \mathrm{cc}$ Standart dan dengan penambahan Ethanol 10\% dan $20 \%$ kami buat dalam bentuk tabel sebagai berikut : 
Tabel 4.8 Perbandingan Uji Torsi Motor Matic 125cc

\begin{tabular}{|c|c|c|c|}
\hline RPM & Standart & E10 & E20 \\
\hline 4500 & 12,43 & & \\
\hline 4500 & & 12,52 & \\
\hline 4500 & & & 12,14 \\
\hline
\end{tabular}

Untuk lebih jelasnya, berikut merupakan grafik Perbandingan Uji Torsi Motor Matic 125cc:

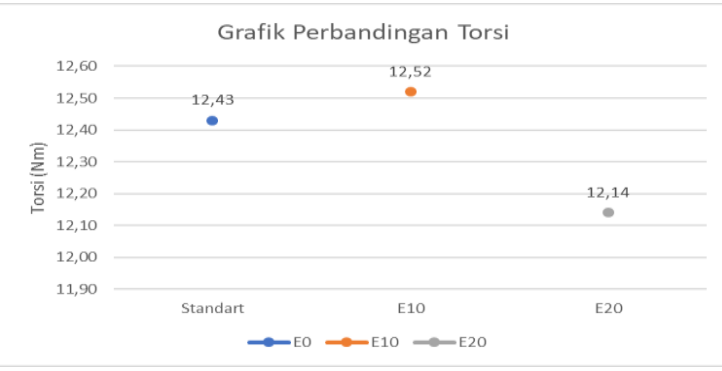

Gambar 4.10 Grafik Perbandingan Torsi

\section{PENUTUP}

\section{Kesimpulan}

Berdasarkan data hasil pengujian dapat diambil kesimpulan tentang pengaruh prosentase penambahan ethanol pada pertalite terhadap uji daya dan torsi pada mesin motor matic $125 \mathrm{cc}$ sebagai berikut :

1. Dari hasil pengujian daya dengan campuran ethanol dan pertalite dari tiap - tiap rpm mengalami perubahan, daya paling rendah pada putaran 3000 rpm sebesar 2,6 HP (pada uji standart), sedangkan daya yang tertinggi pada putaran $6000 \mathrm{rpm}$ sebesar 8,4 HP (pada uji dengan campuran Ethanol 10\%). Selanjutnya torsi pada motor matic $125 \mathrm{cc}$ yang paling terendah pada putaran $3000 \mathrm{rpm}$ sebesar 6,78 $\mathrm{Nm}$ (pada uji standart), sedangkan torsi yang tertinggi pada putaran $4500 \mathrm{rpm}$ sebesar 12,52 Nm (pada uji dengan campuran Ethanol 10\%).

2. Hasil pengujian daya dan torsi dengan campuran ethanol dan pertalite yaitu daya yang dihasilkan dari tiap - tiap rpm mengalami kenaikan. Sedangkan pengujian torsi mengalami kenaikan hingga $4500 \mathrm{rpm}$, dan setelah itu mengalami penurunan.

\section{Saran}

Beberapa saran yang diberikan oleh penulis dari hasil penelitian ini yaitu :

1. Untuk penelitian selanjutnya, sebaiknya dilakukan pengukuran uji emisi gas buang, untuk mengetahui pengaruh prosentase penambahan ethanol dan pertalite terhadap uji emisi gas buang.
2. Seharusnya dalam penelitian harus melihat cara mencampurkan ethanol dan pertalite sebelum melakukan uji daya dan torsi.

3. Sebelum melakukan penelitian, perlu dilakukan uji coba untuk menyesuaikan pengaturan rpm pada motor matic $125 \mathrm{cc}$.

\section{DAFTAR PUSTAKA}

Agrariksa, Fintas Afan, B. Susilo, dan W. A. Nugroho. 2013. Uji Performasi Motor Bakar Bensin (On Chassis) Menggunakan Campuran Premium dan Ethanol. Jurnal Keteknikan Pertanian Tropis dan Biosistem. Vol. 1. No. 3. Hal 194- 203.

Arismunandar, Wiranto. 1977. Penggerak Mula: Motor Bakar Torak. Bandung: Penerbit ITB.

Handayani, Sri Utami. 2007. Pemanfaatan Bio Ethanol Sebagai Bahan Bakar Pengganti Bensin. Gema Teknologi. Vol. 15. No. 2. Hal 99-102.

Keputusan Direktur Jendral Minyak dan Gas Bumi Nomor: 313.K/10/DJM.T/2013 Tentang Standar dan Mutu (Spesifikasi) Bahan Bakar Minyak Jenis Bensin 90 yang Dipasarkan di dalam Negeri. 2013. Jakarta.

Kristanto, Philip, Willyanto, dan Michael. 2001. Peningkatan Unjuk Kerja Motor Bensin Empat Langkah Dengan Penggunaan Methyl Tertiary Buthyl Ether pada Bensin. Jurnal Teknik Mesin. Vol. 3. No. 2. Hal 57-62.

Muchammad. 2010. Analisa Energi Campuran Bioethanol Premium. ROTASI.Vol.12. No. 2. Hal 31-33.

Napitupulu, Farel H. 2006. Pengaruh Nilai Kalor (Heating Value) Suatu Bahan Bakar terhadap Perencanaan Volume Ruang Bakar Ketel Uap Berdasarkan Metode Penentuan Nilai Kalor Bahan Bakar yang Dipergunakan. Jurnal Sistem Teknik Industri. Vol. 7. No. 1. Hal 60-65.

Nurdyastuti, Indyah. 2005. Teknologi Proses Produksi Bio-ethanol.

(ONLINE), http://www.geocities.ws/markal_bppt/publish/biof bbm/biindy.pdf. Diakses pada 26 April 2016.

Raharjo, Winarno Dwi dan Karnowo. 2008. Mesin Konversi Energi. Semarang: Universitas Negeri Semarang Press.

Sarjono dan F. E. A. Putra. 2013. Studi Eksperimen Pengaruh Campuran Bahan Bakar Premium dengan Bioethanol Nira Siwalan terhadap Performa Motor 4 Langkah. Majalah Ilmiah STTR Cepu. No. 16. Hal. 1-11. 
Supraptono. 2004. Bahan Bakar dan Pelumasan. Buku Ajar. Semarang: Jurusan Teknik Mesin Fakultas Teknik Universitas Negeri Semarang.

Winarno, Joko. 2011. Studi Eksperimental Pengaruh Penambahan Bioethanol pada Bahan Bakar Pertamax Terhadap Unjuk Kerja Motor Bensin. Jurnal teknik. Vol. 1. No. 1. Hal 33-39. 